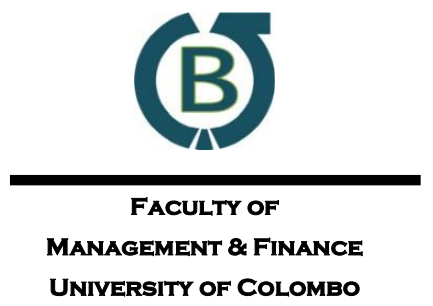

Colombo

Business

Journal

UNIVERSITY OF COLOMBO

INTERNATIONAL JOURNAL OF

THEORY \& PRACTICE

Vol. 11, No. 02, December, 2020

\title{
Impact of Idiosyncratic Volatility on Average Stock Returns: Evidence from Sri Lanka
}

\author{
H. A. P. K. Perera ${ }^{a} \bowtie$, T. C. Ediriwickrama ${ }^{a}$ \\ ${ }^{a}$ Department of Finance, University of Colombo, Sri Lanka
}

\begin{abstract}
The complete diversification of idiosyncratic volatility is questionable due to factors such as market imperfections, investor irrationality and managerial decisions. Therefore, the purpose of this study is to investigate the impact of idiosyncratic volatility on average stock returns in the Sri Lankan context. Using the five-factor asset pricing model of Fama and French (2015) along with Exponential Generalised Autoregressive Conditional Heteroskedasticity (EGARCH) estimated idiosyncratic volatility of stocks of firms listed on the Colombo Stock Exchange (CSE), except for firms in banks, finance and insurance sectors, this study reveals a positive and statistically significant association between average stock returns and idiosyncratic volatility for the sample period from September 2004 to March 2018. The empirical findings on firm profitability and investment yield striking evidence on idiosyncratic volatility of stocks from a frontier market perspective, while uncovering the importance of further research on the investor behaviour on asset pricing decisions.
\end{abstract}

Keywords: CSE, EGARCH, Five-factor Asset Pricing Model, Idiosyncratic Volatility, Sri Lanka

Received:

17 February 2020
Accepted revised version:

22 July 2020
Published:

31 December 2020

Suggested citation: Perera, H. A. P. K., \& Ediriwickrama, T. C. (2020). Impact of idiosyncratic volatility on average stock returns: Evidence from Sri Lanka. Colombo Business Journal. 11(2), 67-92.

DOI: http://doi.org/10.4038/cbj.v11i2.64

(C) 2020 The Authors. This work is licensed under a Creative Commons Attribution 4.0 International License which permits unrestricted use, distribution, and reproduction in any medium, provided the original work is properly cited.

\kasunperera@dfn.cmb.ac.lk: (iD https://orcid.org/0000-0003-0524-308X 


\section{Introduction}

Idiosyncratic volatility is considered to be firm specific, so that it does not move in line with the common movements of the market (Fu, 2009). When estimating the relationship between risk and return of an asset, the Capital Asset Pricing Model (CAPM) assumes investors hold the market portfolio in equilibrium. Hence, it denotes that only market risk should be priced in stock returns as the idiosyncratic volatility can be fully eliminated through diversification (Pukthuanthong-Le \& Visaltanachoti, 2009). However, Merton (1987) argues that, due to existence of information asymmetries in the market, investors cannot fully diversify the idiosyncratic volatility as they are unable to hold a well-diversified portfolio. For instance, Goetzmann and Kumar (2008) depicted that, out of a sample of more than 62,000 households in the United States of America (USA) during the period 19911996 , over $25 \%$ of the investor portfolios have only one stock and more than $50 \%$ of the investor portfolios have no more than three stocks. This shows that the idiosyncratic volatility is an important factor in asset pricing as the investors are holding imperfectly diversified investment portfolios (Merton, 1987).

Although various scholars have found different relationships between idiosyncratic volatility and average stock returns, Bali and Cakici (2008) note that this relationship mainly depends on several factors such as choices of data frequency, portfolio weighting schemes, break point calculations and choice of screens in sample selection. Similarly, Fama (1998) reports that methodology and statistical approaches used in different studies have an impact on the long term returns of stocks.

It is surprising to observe the existence of idiosyncratic volatility in USA as it is considered to be one of the well-performing stock markets in the world (Aabo et al., 2017; Fu, 2009; Guo et al., 2014; Malagon et al., 2015). A considerable body of evidence on idiosyncratic volatility is focused on developed stock markets such as USA. Thus, it is important to investigate the existence of idiosyncratic volatility from another market context and how it affects the asset pricing decisions since the empirical evidence on the role of idiosyncratic volatility on asset pricing decisions is inconclusive ${ }^{1}$.

\footnotetext{
${ }^{1}$ Angelidis (2010) notes that idiosyncratic volatility is lower in emerging markets compared to developed markets. Despite the presence of idiosyncratic volatility puzzle in the developed markets (Ang et al., 2006), Nartea, Ward and Yao (2010) reject the presence of this anomaly in five ASEAN markets (Malaysia, Singapore, Thailand. Indonesia and Philippines). Moreover, Nartea, Wu and Liu (2013) report a negative association between idiosyncratic volatility and stock returns in the Chinese stock market while Liu et al. (2019) record the presence of a positive relation between idiosyncratic volatility and stock returns in China.
} 
Accordingly, the current study revisits the relationship between average stock returns and idiosyncratic volatility in the Sri Lankan context with an updated data set while using the five-factor asset pricing model of Fama and French $(2015)^{2}$. Even though the extant literature, particularly on developed markets, reveals evidence for the relationship between idiosyncratic volatility and average stock returns (Liu et al., 2019; Malagon et al., 2015; Zhong, 2018), it fails to provide evidence on profitability and investments of firms with regard to the same relationship between average stock returns and idiosyncratic volatility from the perspective of a frontier market ${ }^{3}$. Thus, the contribution of the current study to the existing literature is two-fold. Firstly, it provides the empirical evidence on the presence of idiosyncratic volatility from a frontier market point of view while employing the Exponential Generalised Autoregressive Conditional Heteroskedasticity (EGARCH) estimated conditional idiosyncratic volatility to discuss whether the idiosyncratic volatility is priced on the stock returns. Secondly, it investigates the impact of profitability and investment of firms in a frontier market on the idiosyncratic volatility of stocks. The remainder of the paper is organised as follows: The next section discusses the existing literature on idiosyncratic volatility and average stock returns followed by a detailed elaboration on the data and methodology employed in the study. Thereafter, a comprehensive analysis of data is presented. The paper concludes with the limitations of study and avenues for further research.

\section{Literature Review}

Markowitz (1952) quantifies the concept of diversification through the portfolio selection problem which laid the foundation for the Modern Portfolio Theory (MPT). This theory argues that the risk of failures in investments increases when all the money is invested in a single asset. However, Fabozzi et al. (2002), highlight that portfolio selection is a normative theory which explains what the investors should pursue, and not what is being actually followed by them when constructing and selecting investment portfolios. In contrast, the asset pricing theory is a positive theory which attempts to hypothesise how the investors behave rather than how they should behave by estimating the expected return of a portfolio constructed based on mean-variance analysis (Fabozzi et al., 2002). Thus, the asset pricing theory attempts to build a relationship between return of an asset and its risk.

\footnotetext{
${ }^{2}$ Pukthuanthong-Le and Visaltanachoti (2009) examine the pricing of idiosyncratic volatility by using the CAPM where Sri Lankan stock market has been given only a cursory attention in that study.

${ }^{3}$ Uludag and Ezzat (2016) note that frontier markets are more attractive to international investors due to their growth potentials and profits. Hence, to allocate larger amount of funds to frontier markets, the investor confidence on the diversification efficiency of frontier markets is important. Sri Lanka is categorised as a frontier market in the Morgan Stanley Capital International (MSCI) classification.
} 
The asset pricing theory marked its birth with the CAPM which is based on Markowitz's portfolio selection model. Although the CAPM argues that a diversified portfolio is capable of avoiding certain inherent risks of an asset, it lacks a clear demarcation of which particular risk component is relevant for the price of an asset (Sharpe, 1964). Moreover, despite the fact that the CAPM offers powerful predictions on the measurement of risk and relationship between return and risk of an asset, the empirical record of the model is poor mainly due to its simplifying assumptions (Fama \& French 2004). Therefore, different asset pricing models have been developed thereafter by incorporating several factors to determine the price of an asset. For instance, arbitrage pricing model (Ross, 1976), three-factor asset pricing model (Fama \& French, 1993), four-factor asset pricing model (Carhart, 1997) and five-factor asset pricing model (Fama \& French, 2015) have been developed to tackle with the relationship between the risk and return of an asset.

According to Merton (1987), the asset pricing models assume all publicly available information disseminates across all investors at the same time and they act upon them immediately as they receive them. Hence, he argues that the financial models are built on the assumptions of availability of complete information and frictionless markets. However, different scholars have empirically proven the existence of various trading frictions in the market. For instance, price delay (Hou \& Moskowitz, 2005), charging a higher level of taxes on dividends than long term capital gains (Miller \& Scholes, 1982), illiquidity (Pastor \& Stambaugh, 2003; Amihud, 2002; Amihud \& Mendelson, 1986) are some of the important trading frictions in the market highlighted by scholars. More importantly, Kumar (2009) shows there is a set of individuals who are willing to hold 'lottery-like' securities, where he defines such securities as low-priced securities with high idiosyncratic volatility in the context of the stock market. Similarly, Bali, Cakici, and Whitelaw (2011) confirm that imperfect diversification influences investors to hold 'lotterylike' assets, and this question the validity of the assumption of asset pricing models, that no compensation is required for holding idiosyncratic volatility.

Idiosyncratic volatility is assumed to be completely excluded through diversification so that the conventional CAPM theory suggests that only market risk should be priced in equilibrium (Malkiel \& Xu, 2006). However, Merton (1987) argues that the asset pricing models are inadequate to capture the rationality of diversification decisions of the investors due to information asymmetry in the market. In addition, Malagon et al. (2015) highlight that managerial decisions are directly linked with the idiosyncratic volatility. Hence, they argue that in addition to the 
investor irrationality and market imperfections, idiosyncratic volatility is also caused by the decisions of managers on business operations. Moreover, Ang et al. (2009) show that there is a likelihood of generating a link between average stock returns and idiosyncratic volatility in the presence of incorrectly specified factor models along with incomplete information and market frictions. Thus, it highlights the importance of the role of idiosyncratic volatility in asset pricing decisions ${ }^{4}$.

The idiosyncratic volatility has been estimated in different methods and frequencies in the previous studies. For instance, Bali, Engle and Murray (2016) estimate the idiosyncratic volatility on the basis of, one month, three months, six months, twelve months, one year, two years, three years and five years while Kumari et al. (2017), Fu (2009), Pukthuanthong-Le and Visaltanachoti (2009) and Xu and Malkiel (2003) estimate the idiosyncratic volatility on a monthly basis. Furthermore, in certain previous studies, one month lagged idiosyncratic volatility has been used to estimate the idiosyncratic volatility (Ang et al., 2006, 2009; Bali \& Cakici, 2008; Bali, Engle \& Murray, 2016; Malagon et al., 2015).

On the contrary, while highlighting the theoretical and empirical errors in estimating the idiosyncratic volatility using the one month lagged idiosyncratic volatility, certain scholars suggest the EGARCH technique of Nelson $(1991)^{5}$ as a better technique to estimate the idiosyncratic volatility (Kumari et al., 2017; Fu, 2009; Pukthuanthong-Le \& Visaltanachoti, 2009). As highlighted by Bali and Cakici (2008), the existence of methodological differences among previous studies led to conflicting arguments and thereby creation of a substantive puzzle in relation to the idiosyncratic volatility. As a result, Fu (2009) notes the importance of quality estimation of idiosyncratic volatility in deriving at the inferences between average returns and idiosyncratic volatility. Fu (2009) further argues that estimation of idiosyncratic volatility warrants a special attention due to its time varying property. Liu et al. (2019), and Pukthuanthong-Le and Visaltanachoti (2009), studies that put forth similar arguments, find that idiosyncratic volatility is changing over time.

\footnotetext{
${ }^{4}$ Jiang et al. (2009) identify the information content of idiosyncratic volatility and note that idiosyncratic volatility links with the level of corporate information disclosures. Hence, they argue that strategic behaviour of the companies in disclosing the information directly affect idiosyncratic volatility of sticks.

${ }^{5}$ Nelson (1991) notes that EGARCH model captures the asymmetric property of volatility which denotes an increase in the risk of the firm due to leverage effect. Moreover, Engle and $\mathrm{Ng}$ (1993) indicate that EGARCH model is appropriate in capturing asymmetry of conditional volatility where EGARCH does not require to impose any artificial non-negativity constraints on the model parameters (Brooks, 2008).
} 
$\mathrm{Fu}$ (2009) criticises the idiosyncratic volatility estimation process and the inferences made thereon by Ang et al. (2006). The empirical method of Ang et al. (2006) implicitly assumes that the time varying property of idiosyncratic volatility can be approximated by a random walk process. However, based on the United States data, Fu (2009) empirically demonstrates that idiosyncratic volatility of stocks does not follow a random walk. Confirming the findings of Fu (2009), based on a sample of individual stock data across 36 countries, Pukthuanthong-Le and Visaltanachoti (2009) highlight that lagged idiosyncratic volatility of a stock in the current month is not an appropriate measurement to predict the next month's average return of a stock as it leads to severe measurement errors. Thus, the empirical evidence of Liu et al. (2019), Fu (2009) and Pukthuanthong-Le and Visaltanachoti (2009) overwhelmingly highlight that it is inappropriate to use lagged idiosyncratic volatility of stocks to derive at the inferences between average stock returns and idiosyncratic volatility. Hence, they question the applicability of findings of Ang et al. (2006) on empirical grounds.

Further, Fu (2009), Bali and Cakici (2008) and Xu and Malkiel (2003) empirically found that stocks with high idiosyncratic volatility are small in size and illiquid while Amihud (2002) shows that illiquidity leads to the generation of higher returns and this trading friction of illiquidity mainly affects the returns of small firms. Hence, it once again questions the appropriateness of the idiosyncratic volatility estimated through the realised returns. This highlights the appropriateness of the EGARCH technique to estimate the idiosyncratic volatility. Guo et al. (2014) further note that the use of the EGARCH estimated idiosyncratic volatility leads to sound theoretical explanations of stock returns. However, Guo et al. (2014) also note that there is a significant look-ahead biasness in in-sample EGARCH idiosyncratic volatility estimates which is a limitation of this method of estimating the idiosyncratic volatility of stocks. ${ }^{6}$

It is also important to examine how the idiosyncratic volatility links with other firm specific variables such as profitability and investments. For instance, based on the empirical investigations in the USA, Jiang et al. (2009) show that corporate disclosures on the business performance lead to the creation of a firm specific risk while Malagon et al. (2015) note that managerial decisions on inventory and receivables management, profitability and investment have a direct link with the

\footnotetext{
${ }^{6}$ Guo et al. (2014) further argue that the EGARCH estimates are highly sensitive to small samples where addition of one extra monthly return creates a major impact on statistical inferences due to look-ahead biasness.
} 
idiosyncratic volatility. Even though these empirical findings shed light on the idiosyncratic volatility and its associations with other firm specific factors from the perspective of developed markets, the extant literature lacks adequate empirical evidence to discuss these aspects from the perspective of frontier markets.

\section{Methodology}

\section{Sample and Data}

The population of the study consists of all the listed companies on the Colombo Stock Exchange (CSE). However, following Abeysekera and Nimal (2016), Samarakoon (1996) and Fama and French (1992), this study has excluded the companies listed under the Banks, Finance and Insurance sector and stocks with negative book-to-market ratio from the sample. This is because the higher leverage is a common characteristic for finance companies, and it does not have the same meaning with regard to non-finance companies where high leverage is more likely to indicate distress risk (Fama \& French, 1992).

Accordingly, the authors have obtained the monthly stock prices and other accounting details pertinent to 214 companies listed on the CSE over a period of 163 months from September 2004 to March 2018 $8^{7}$. The required data has been obtained from the annual reports of the listed companies, CSE data library and annual reports of the Central Bank of Sri Lanka. The EViews 10 software package has been used to estimate the relevant models.

\section{Operationalisation}

Table 1 shows the research models (Panel A) and variables (Panel B) used in the current study. The dependent variable of the current study is the monthly stock returns calculated for each individual stock. The Equation (1) shows the explicit functional form of calculating the monthly stock returns where $R_{i t}$ is the monthly return of stock $i$ at time $t$ which is calculated as the natural logarithm of the closing price of stock $i$ at month $t\left(P_{i t}\right)$ as a fraction of the closing price of stock $i$ at the previous month $t-1$ $\left(P_{i t-1}\right)$. Following Sriyalatha (2008), monthly stock returns are adjusted for bonus issues and rights issues (see Appendix 1).

$$
R_{i t}=\ln \left(\frac{P_{i t}}{P_{i t-1}}\right)
$$

\footnotetext{
${ }^{7}$ The all share total return index (ASTRI) is the proxy for market return used in the current study and ASTRI was introduced in the CSE in the year 2004.
} 
Since the purpose of the study is to investigate the influence of idiosyncratic volatility on average stock returns, the main independent variable of the study is the idiosyncratic volatility of each stock. Accordingly, following Fu (2009), the authors have employed the EGARCH $(p, q)$ model of Nelson (1991) to estimate the idiosyncratic volatility of stocks ${ }^{8}$. Hence, this study has employed $1 \leq p \leq 3,1 \leq q \leq 3$ order where the permutation of these orders generate nine different EGARCH models: EGARCH $(1,1)$, EGARCH $(1,2)$, EGARCH $(1,3)$, EGARCH $(2,1)$, EGARCH $(2,2)$, EGARCH $(2,3)$, EGARCH $(3,1)$, EGARCH $(3,2)$, and EGARCH $(3,3)$. Each model has employed for each stock independently and Akaike Information Criterion (AIC) has been used to determine the best model for each stock $^{9}$. The square root of the conditional variance from the five-factor asset pricing model residuals estimated using an EGARCH model is the idiosyncratic volatility (EIVOL) of stocks. Further, in order to overcome the look-ahead biasness problem, following Fu (2009) and Pukthuanthong-Le and Visaltanachoti (2009), current study requires firms to have at least 30 monthly return observations.

Furthermore, in order to examine the impact of each risk factor of the five-factor asset pricing model, the authors have controlled the relationship between average stock returns and idiosyncratic volatility (Model 02) for each risk factor or combination of risk factors of the asset pricing model used in the study (Model 03 to Model 07). Accordingly, the association between average stock returns and idiosyncratic volatility is controlled for market risk premium, size, value, profitability and investment factors.

\section{Factor Construction}

For the purpose of construction of size, value, profitability and investment factors, portfolios need to be formed. Since the Sri Lankan listed companies have two financial year-end periods, namely $31^{\text {st }}$ of December and $31^{\text {st }}$ of March, the CSE requires them to publish their audited financial statements within six months from the financial year-end date. Therefore, following Abeysekera and Nimal (2016) and Samarakoon (1996), 30 ${ }^{\text {th }}$ of September of each year has been chosen as the portfolio formation date for the purpose of factor construction in the current study. Hence, the portfolios have been formed at the end of September of each year $t$, and they have been reformed at the end of September $t+1$. Further, Abeysekera and Nimal (2016)

\footnotetext{
${ }^{8}$ Before estimating the EGARCH models, the ARCH-LM test was performed for all 214 stocks in the sample independently and the results are not reported to conserve space.

${ }^{9}$ The parameter estimates of EGARCH for all 214 are not produced to conserve space and they can be made available on request.
} 
Table 1: Research Models and Variables

Panel A: Statistical Models

Model A $1 \quad$ Equation

$\operatorname{EGARCH}(p, q)$

Model 01 (Mean equation)

$R_{i t}-R_{f t}=\alpha_{i}+b_{i}\left(R_{m t}-R_{f t}\right)+s_{i} S M B_{t}+h_{i} H M L_{t}+r_{i} R M W_{t}+c_{i} C M A_{t}+\varepsilon_{i t}$ where $\varepsilon_{i t} \sim N\left(0, \sigma_{i t}^{2}\right)$

Model 01 (Variance

equation)

$\ln \sigma_{i t}^{2}=\alpha_{i}+\sum_{l=1}^{p} b_{i, l} \ln \sigma_{i, t-l}^{2}+\sum_{k=1}^{q} c_{i, k}\left\{\theta\left(\frac{\varepsilon_{i, t-k}}{\sigma_{i, t-k}}\right)+\gamma\left[\left|\frac{\varepsilon_{i, t-k}}{\sigma_{i, t-k}}\right|-\sqrt{\frac{2}{\pi}}\right]\right\}$

\section{Model A 2}

\section{Equation}

OLS Regressions

Model 02

$\bar{R}_{t}=\lambda_{0}+\lambda_{1} \operatorname{EIVOL}_{t}+u_{t}$

Model 03

Model 04

$\bar{R}_{t}=\lambda_{0}+\lambda_{1} E_{\text {IVOL }}+\lambda_{2}\left(R_{m}-R_{f}\right)_{t}+u_{t}$

$\bar{R}_{t}=\lambda_{0}+\lambda_{1}$ EIVOL $_{t}+\lambda_{2} S M B_{t}+u_{t}$

Model 05

$\bar{R}_{t}=\lambda_{0}+\lambda_{1} E_{I V O L}+\lambda_{2} H M L_{t}+u_{t}$

Model 06

$\bar{R}_{t}=\lambda_{0}+\lambda_{1} E_{\text {IVOL }}+\lambda_{2} R M W_{t}+u_{t}$

Model 07

$\bar{R}_{t}=\lambda_{0}+\lambda_{1} E_{I V O L}+\lambda_{2} C M A_{t}+u_{t}$

Model 08

$\bar{R}_{t}=\lambda_{0}+\lambda_{1} E_{\text {EIVOL }}+\lambda_{2}\left(R_{m}-R_{f}\right)_{t}+\lambda_{3} S M B_{t}+\lambda_{4} H M L_{t}+\lambda_{5} R M W_{t}+\lambda_{6} C M A_{t}+u_{t}$

Model 09

$\bar{R}_{t}=\lambda_{0}+\lambda_{1} E_{I V O L}+\lambda_{2}\left(R_{m}-R_{f}\right)_{t}+\lambda_{3} S M B_{t}+\lambda_{4} R M W_{t}+\lambda_{5} C M A_{t}+u_{t}$ 


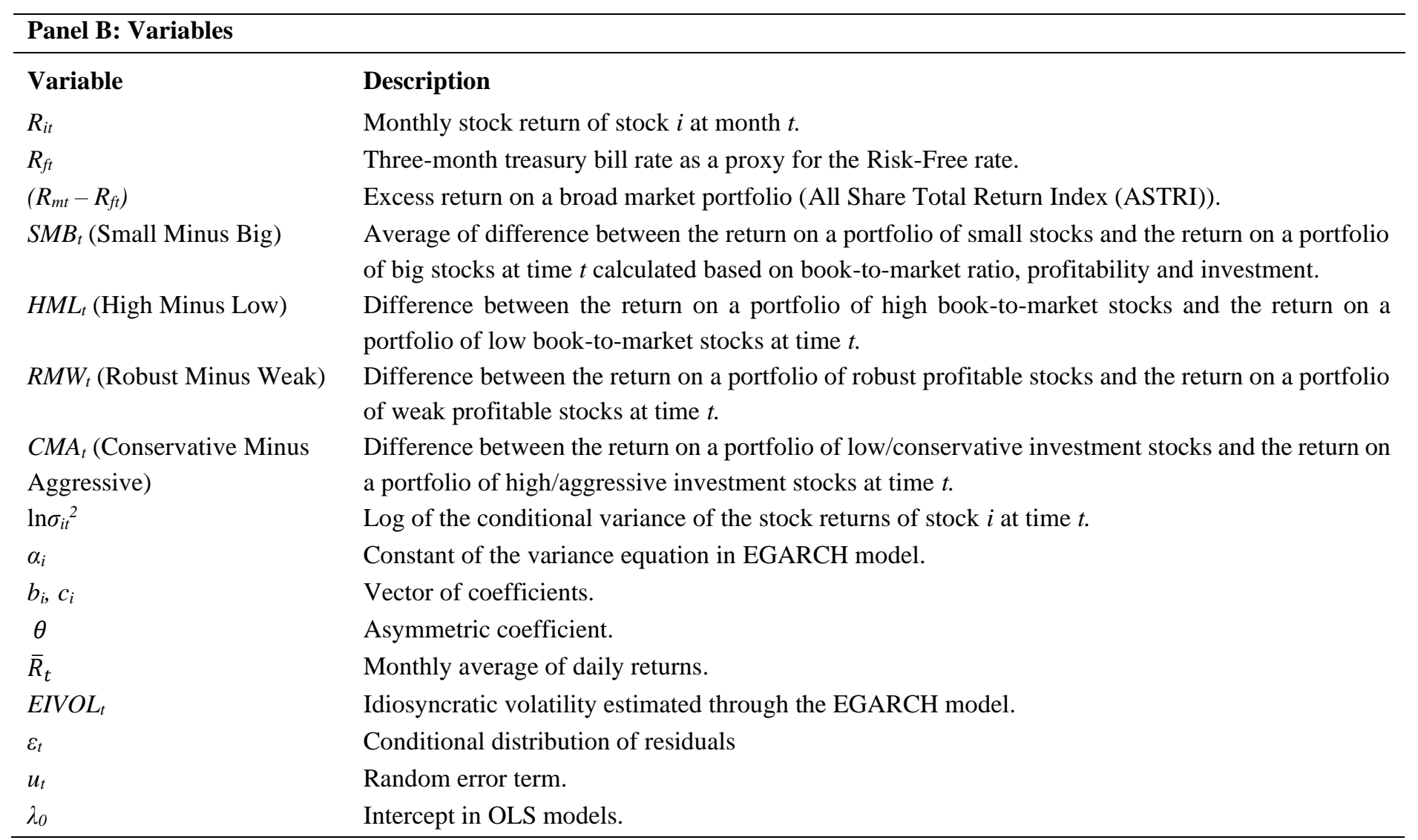

Note: Based on Nelson (1991) and Fama and French (2015). The conditional variance $\left(\sigma_{i t}^{2}\right)$ in the variance equation of Model 01, is a function of past p-period of residual variance and past $q$-period of return shocks. The $\varepsilon_{i t}$ and $u_{t}$ are the residual terms of the mean equation of Model 01 in Model A 1 and OLS models, Model 02 to Model 09, in Model A2 respectively. The factor construction is described in detail in Table 2. 
note that this approach for portfolio formation in order to calculate the risk factors helps to avoid the problem of look-ahead biasness.

The market risk premium is calculated as the excess of All Share Total Return Index (ASTRI) return over risk-free rate of return (i.e. three-month government treasury bill rate) (Abeysekera \& Nimal, 2016). On the other hand, market size (Size) is determined through the market capitalisation of each stock (Ang et al., 2006; Ediriwickrama, 2018; Fama \& French, 1992; Fu, 2009) while the value of each stock is calculated through the book-to-market $(B / M)$ equity ratio of each firm (Ang et al., 2006; Ediriwickrama, 2018; Fama \& French, 1992; Fu, 2009). Moreover, the profitability (Prof) of each firm is determined by calculating the net profit of the firm as a fraction of its book equity (Ediriwickrama, 2018) whereas the growth of total assets of the firm is used to calculate the investment (Inv) of each stock (Ediriwickrama, 2018; Fama \& French, 2015).

Table 2: Construction of Size, Value, Profitability and Investment Factors

\begin{tabular}{lll}
\hline Sort & Breakpoints & Factors and their components \\
\hline $2 \times 3$ sorts on & Size: CSE & $S M B_{B / M}=(S L+S N+S H) / 3-(B L+B N+B H) / 3$ \\
Size and $B / M$, & median & $S M B_{\text {Porf }}=(S R+S N+S W) / 3-(B R+B N+B L) / 3$ \\
or Size and & & $S M B_{\text {Inv }}=(S A+S N+S C) / 3-(B A+B N+B C) / 3$ \\
Prof, or Size & & $S M B=\left(S M B_{B / M}+S M B_{P r o f}+S M B_{I n v}\right) / 3$ \\
and Inv & B/M: $30^{\text {th }}$ and & $H M L=(S H+B H) / 2-(S L+B L) / 2$ \\
& $70^{\text {th }}$ percentiles & \\
& $\begin{array}{l}\text { Prof: } 30^{\text {th }} \text { and } \\
70^{\text {th }} \text { percentiles }\end{array}$ & $R M W=(S R+B R) / 2-(S W+B W) / 2$ \\
& Inv: $30^{\text {th } \text { and }}$ & $C M A=(S C+B C) / 2-(S A+B A) / 2$ \\
& $70^{\text {th }}$ percentiles & \\
\hline
\end{tabular}

Note: Based on Fama and French (2015). Size, B/M, Prof and Inv are market capitalisation, book-tomarket ratio, profitability and investment respectively. In the $2 \times 3$ sorts, the Size group, Small (S), Neutral (N) or Big (B), the $B / M$ group, High (H), Neutral (N) or Low (L), the Prof group, robust $(\mathrm{R})$, neutral $(\mathrm{N})$ or weak $(\mathrm{W})$, the Inv group, conservative $(\mathrm{C})$, neutral $(\mathrm{N})$ or aggressive $(\mathrm{A})$. The factors are $S M B$ (Small Minus Big), HML (High Minus Low B/M), RMW (Robust Minus Weak Prof), CMA (Conservative Minus Aggressive Inv).

Moreover, the Size breakpoint is the median market capitalization while $B / M$, Prof and Inv breakpoints are the $30^{\text {th }}$ and $70^{\text {th }}$ percentiles of $B / M$, Prof and Inv for stocks. In addition to conventional Size factor $\left(S M B_{B / M}\right)$, the use of $2 \times 3$ sorts to construct $R M W$ and $C M A$ factors produce two additional Size factors namely, $S M B_{\text {Porf }}$ and $S M B_{I n v}$. Therefore, Size factor $(S M B)$ from the three $2 \times 3$ sorts is defined as the 
average of $S M B_{B / M}, S M B_{\text {Porf }}$ and $S M B_{\text {Inv }}$. Table 2 shows a summary of factor construction in the current study.

\section{Analysis and Discussion}

\section{Descriptive Statistics}

The descriptive statistics of the variables used in the study are presented in Table 3. Accordingly, it shows that the mean value of the average stock returns of the individual stocks is $0.93 \%(t=1.655)$ with a standard deviation of $7.15 \%$. Moreover, the mean value of the market risk premium $\left(R_{m}-R_{f}\right)$ is found to be $-8.89 \%(t=-15.233)$ with a higher standard deviation of $7.42 \%$. In fact, the market risk premium records the highest volatility where similar findings record in relation to the CSE (Abeysekera \& Nimal, 2016, 2017) and Asian countries (Ang et al., 2009).

Table 3. Descriptive Statistics

\begin{tabular}{lrrrrrrr}
\hline & $\bar{R}$ & $R_{m}-R_{f}$ & $S M B$ & $H M L$ & $R M W$ & $C M A$ & EIVOL \\
\hline Mean & $0.93 \%$ & $-8.89 \%$ & $0.37 \%$ & $0.60 \%$ & $0.45 \%$ & $0.06 \%$ & $10.61 \%$ \\
Std. Dev. & $7.15 \%$ & $7.42 \%$ & $3.04 \%$ & $4.22 \%$ & $3.82 \%$ & $3.27 \%$ & $1.81 \%$ \\
$t$-Mean & 1.655 & -15.233 & 1.542 & 1.798 & 1.506 & 0.241 & 74.758 \\
\hline
\end{tabular}

Note: $\bar{R}$ is the monthly average of daily returns. $R_{m}-R_{f}$ is the market factor where the market risk premium is the excess of ASTRI return over risk-free rate of return (i.e. three-month government treasury bill rate). $S M B$ is the monthly size factor where $H M L$ is the monthly value factor. $R M W$ and $C M A$ are monthly profitability and investment risk factors respectively. EIVOL is the monthly idiosyncratic volatility of stocks estimated through the EGARCH model by using Fama and French (2015) five-factor asset pricing model as the mean equation.

The size factor $(S M B)$ has recorded a mean value of $0.37 \%(t=1.542)$ with a standard deviation of $3.04 \%$ for the period under consideration in the current study. The result of mean value of size factor closer to zero is in line with previous findings such as Abeysekera and Nimal $(2016,2017)$. The average value factor $(H M L)$ per month is found to be $0.6 \%(t=1.798)$ with a standard deviation of $4.22 \%$ with respect to the CSE. This finding is closely in line with the previous findings of Abeysekera and Nimal $(2016,2017)$ in the Sri Lankan context while it also supports the results in the Asian (Ang et al., 2009) and Asia Pacific (Fama \& French, 2012) contexts.

As per Table 3, the average profitability $(R M W)$ is found to be $0.45 \%(t=1.506)$ per month with a standard deviation of $3.82 \%$. On the other hand, the mean value of the investment factor $(C M A)$ is found to be $0.06 \%(t=0.241)$ with a standard deviation of $3.27 \%$. However, these findings in relation to the CSE is somewhat 
contrasting to the findings in the Asia Pacific (Fama \& French, 2017). The descriptive statistics further demonstrate a mean value of $10.61 \%(t=74.758)$ for the idiosyncratic volatility. However, Pukthuanthong-Le and Visaltanachoti (2009) in their cross country analysis, report a relatively higher mean value for Sri Lanka. ${ }^{10}$

\section{Regression Results}

Table 4 depicts the regression results with respect to Models from 02 to 09.

\section{Model 02}

Interestingly, a positive and statistically significant relation is found between average stock returns and idiosyncratic volatility of stocks in all eight regressions specified in the study. The univariate regression of average stock returns on idiosyncratic volatility of stocks specified in the Model 02 depicts a positive and statistically significant relation between average stock returns and idiosyncratic volatility. Further, these findings are in line with the empirical findings of Fu (2009), Pukthuanthong-Le and Visaltanachoti (2009) with respect to idiosyncratic volatility and average stock returns, Thus, it is clear that idiosyncratic volatility matters in asset pricing in the Sri Lankan context. Therefore, it rejects the notion that idiosyncratic volatility should not be priced in equilibrium as it can be fully diversified.

\section{Model 03}

Even though the regression results demonstrate a positive and statistically significant relation between average stock returns and idiosyncratic volatility in all regression specifications of the study, the magnitude of the association is substantially varying from one model to another. For instance, the magnitude of the idiosyncratic volatility is relatively high in Model 03 (0.7795) compared to Model 02 (0.7093). When the market risk factor is added to the Model 03, the regression coefficient of idiosyncratic volatility becomes substantially large. In fact, Model 03 has recorded the highest magnitude for the idiosyncratic volatility out of the eight OLS regression models specified in the study. Further, a positive and statistically significant market factor can also be observed where similar positive and statistically significant market factor is reported by Abeysekera and Nimal (2017) in the Sri Lankan context.

This clearly confirms that market risk or systematic risk is not the only risk that should be priced in equilibrium. Hence, it clearly supports the argument of Merton (1987) that the investors do consider total risk but not only the market risk. Thus, the

\footnotetext{
${ }^{10}$ Pukthuanthong-Le and Visaltanachoti (2009) report a mean idiosyncratic volatility value of $15.98 \%$ for Sri Lanka while it ranges from $8.73 \%$ (Switzerland) to as high as $21.93 \%$ (India).
} 
Table 4: Regression Results

\begin{tabular}{|c|c|c|c|c|c|c|c|c|}
\hline & Model 02 & Model 03 & Model 04 & Model 05 & Model 06 & Model 07 & Model 08 & Model 09 \\
\hline \multirow[t]{2}{*}{ C } & $-0.0647 * *$ & -0.0366 & -0.0498 & $-0.0666 * *$ & $-0.0689 * *$ & $-0.0665^{* *}$ & -0.0331 & -0.0338 \\
\hline & $(-2.1489)$ & $(-1.3824)$ & $(-1.5658)$ & $(-2.1276)$ & $(-2.2047)$ & $(-2.1908)$ & $(-1.2626)$ & $(-1.2722)$ \\
\hline \multirow[t]{2}{*}{ EIVOL } & $0.7093 * *$ & $0.7795 * * *$ & $0.5291 *$ & $0.7180^{* *}$ & $0.7285 * *$ & $0.7267 * *$ & $0.7767 * * *$ & $0.7290 * * *$ \\
\hline & $(2.5288)$ & (3.1904) & (1.7816) & (2.4638) & (2.5047) & $(2.5700)$ & (3.1871) & (2.9635) \\
\hline \multirow[t]{2}{*}{$R_{m}-R_{f}$} & & $0.4349 * * *$ & & & & & $0.4709 * * *$ & $0.4293 * * *$ \\
\hline & & (7.2957) & & & & & $(7.5731)$ & (7.1357) \\
\hline \multirow[t]{2}{*}{$S M B$} & & & $0.3852 * *$ & & & & 0.1988 & 0.2407 \\
\hline & & & $(2.1836)$ & & & & $(1.3145)$ & (1.5828) \\
\hline \multirow[t]{2}{*}{$H M L$} & & & & -0.0805 & & & $-0.2530^{* *}$ & \\
\hline & & & & $(-0.7391)$ & & & $(-2.2533)$ & \\
\hline \multirow[t]{2}{*}{$R M W$} & & & & & 0.1609 & & 0.1586 & $0.2241^{*}$ \\
\hline & & & & & (1.1781) & & (1.2967) & (1.8621) \\
\hline \multirow[t]{2}{*}{$C M A$} & & & & & & -0.0893 & 0.0731 & 0.1408 \\
\hline & & & & & & $(-0.5688)$ & $(0.5270)$ & $(1.0261)$ \\
\hline Adjusted $\mathrm{R}^{2}$ & 0.2033 & 0.3940 & 0.1146 & 0.1419 & 0.1464 & 0.1999 & 0.4195 & 0.4040 \\
\hline$F$ statistics & $11.2710^{* * *}$ & $21.9339 * * *$ & $7.9461 * * *$ & $7.6544 * * *$ & $7.9050 * * *$ & $9.0426 * * *$ & $13.9253 * * *$ & $14.6411 * * *$ \\
\hline Observations & 162 & 162 & 162 & 162 & 162 & 162 & 162 & 162 \\
\hline
\end{tabular}

Notes: $1 . \bar{R}$ is the monthly average of daily stock returns. $R_{m}-R_{f}$ is the market factor where the market risk premium is the excess of ASTRI return over risk-free rate of return (i.e., three-month government treasury bill rate). $S M B$ is the monthly size factor where $H M L$ is the monthly value factor. $R M W$ and $C M A$ are monthly profitability and investment risk factors respectively. EIVOL is the monthly idiosyncratic volatility of stocks estimated through the EGARCH model by using Fama and French (2015) five-factor asset pricing model as the mean equation.

2. ***, ** and $*$ denote significance levels $p<0.01, p<0.05$ and $p<0.1$, respectively and $t$ statistics are reported in parentheses 
investors expect a premium on idiosyncratic volatility (Bali \& Cakici, 2008; Merton 1987). These findings are in line with Pukthuanthong-Le and Visaltanachoti (2009) in the Sri Lankan context. However, there is a slight difference in the empirical findings between the current study and Pukthuanthong-Le and Visaltanachoti (2009) in terms of the magnitude of idiosyncratic volatility where the latter reports a lower magnitude (0.1201) for the idiosyncratic volatility. Nevertheless, as Bali and Cakici (2008) highlight, the presence of methodological differences in the studies can generate different empirical outcomes.

\section{Model 04}

The Model 04 demonstrates the relation between average stock returns and idiosyncratic volatility after controlling for the size effect. Albeit the relation between average stock returns and idiosyncratic volatility is positive, it is marginally significant at $10 \%$ level of significance. More interestingly, coefficient of the idiosyncratic volatility records the lowest magnitude out of the eight OLS regression models specified in the study. However, this is not a surprising empirical finding.

According to Fu (2009), Bali and Cakici (2008), Ang et al. (2006) and Hou and Moskowitz (2005) the idiosyncratic volatility is high with small stocks. On the other hand, in the conventional size effect Fama and French (1993) argue that small firms generate higher average returns where in the current study, size factor is found to be positive and statistically significant in relation to the average stock returns. Thus, when the relationship between average stock returns and idiosyncratic volatility is controlled for the size effect, the positive correlation between average stock returns and idiosyncratic volatility should become weaker. The regression results in Table 4 exactly demonstrate this phenomenon.

\section{Model 05}

The relationship between average stock returns and idiosyncratic volatility is controlled for value effect by adding value factor as an independent variable in the Model 05. Accordingly, the regression results in Table 4 demonstrate a positive and statistically significant relation between average stock returns and idiosyncratic volatility. On the other hand, value effect is found to be negative and statistically insignificant. This finding is quite interesting as it clearly contradicts with the widely documented value effect that valued firms generate higher average returns.

However, Fama and French (2015) note that the value factor $(H M L)$ is a redundant factor in the five-factor asset pricing model as the exposure of the value 
factor to other factors in the model has absorbed mean $H M L$ return. Fama and French (2017) reconfirm the redundancy issue of value factor by testing the five-factor asset pricing model at the global level ${ }^{11}$. Since, the present study has employed Fama and French (2015) five-factor asset pricing model to estimate the idiosyncratic volatility, the aforementioned reason could be the cause for this negative relationship. A relationship of similar type can be observed in Model 08 with respect to the value factor. Furthermore, Fama and French (2015) highlight that $H M L$ is incapable of improving and constructing a mean-variance-efficient tangency portfolio by combining the risk-free assets along with the other risk factors (i.e. market factor, size factor, profitability factor and investment factor). In other words, this indicates that the investors are unable to fully diversify away the idiosyncratic volatility. Hence, they would demand an idiosyncratic volatility premium over their investments. Based on this argument, it is evident that if the value factor $(H M L)$ is included in regression model, then the magnitude of the idiosyncratic volatility should be stronger. This idea can be clearly observed through the results of the Model 05 (see Table 4) where the magnitude of the idiosyncratic volatility is much stronger compared to the magnitude of the idiosyncratic volatility reported in Model 02.

\section{Model 06}

In Addition to the above empirical findings, the results of Models 06 to 08 depicted in Table 4 yield novel striking evidence with respect to idiosyncratic volatility of stocks. According to the Model 06, when the relation between average stock returns and idiosyncratic volatility is controlled for the profitability of firms by adding profitability factor as an independent variable, the idiosyncratic volatility shows a positive and statistically significant relation with the average stock returns. Further, the magnitude of the coefficient is also relatively higher compared to the coefficient reported in Model 02.

The fact that the positive relation of idiosyncratic volatility with the average stock returns has become even stronger after controlling for the profitability indicates that investors might expect a higher compensation for bearing the idiosyncratic volatility. This is novel and interesting empirical evidence on idiosyncratic volatility. Albeit its positive relation with the average stock returns, the profitability factor is found to be statistically insignificant. This could be a reason for less strong positive relation between average stock returns and idiosyncratic volatility.

\footnotetext{
${ }^{11}$ Fama and French (2017) globally test the application of five-factor asset pricing model by identifying four regions: North America, Europe, Asia Pacific and Japan.
} 


\section{Model 07}

Another featuring evidence of this study in relation to the idiosyncratic volatility is depicted in Model 07 (see Table 4). That is the impact of investment factor on the association between average stock returns and idiosyncratic volatility of stocks. Accordingly, the results show a positive and statistically significant relation between average stock returns and idiosyncratic volatility of stocks when it is controlled for the investment factor. Similar to previous findings on profitability, a much stronger positive relation between average stock returns and idiosyncratic volatility is found in Model 07.

This result perhaps indicates that the investment in assets is lower for firms with high idiosyncratic volatility. Thus, it sheds the light on the argument of Merton (1987) that investors expect a higher compensation for high idiosyncratic volatility. However, perhaps the negative and statistically insignificant relation of investment factor with the average stock returns might be a reason for a positive but less strong relation between average stock returns and idiosyncratic volatility.

\section{Model 08}

The full specification of the five-factor asset pricing model is depicted in Model 08 (see Table 4). The empirical results of this model are in line with the previous discussion of this section. However, the striking evidence with respect to the idiosyncratic volatility is that Model 08 records the second strongest positive relation between average stock returns and idiosyncratic volatility along with the highest adjusted $\mathrm{R}$ squared value of approximately $42 \%$. Hence, these empirical findings confirm that idiosyncratic volatility matters in asset pricing in the Sri Lankan context. Furthermore, with the presence of empirical evidence on the positive association between average stock returns and idiosyncratic volatility emphasises that investors demand a higher compensation for stocks with higher idiosyncratic volatility. More importantly, this empirical finding of positive association between average stock returns and idiosyncratic volatility is clearly in line with the previous empirical findings such as Kumari et al. (2017), Fu (2009), and Pukthuanthong-Le and Visaltanachoti (2009).

Further, results in Model 08 highlight the redundancy problem of value factor in the five-factor asset pricing model as emphasised by Fama and French $(2015,2017)$. Hence, Fama and French (2015) allow to drop the value factor from the five-factor model. Accordingly, the Model 09 depicts the empirical results without incorporating the value factor into the model. 


\section{Model 09}

The empirical results of this model support the previous findings of this study highlighting the positive and statistically significant relation between average stock returns and idiosyncratic volatility. Moreover, the adjusted $\mathrm{R}$ squared of approximately $40 \%$ of the model indicates the validity of the redundancy effect of value factor as the explanatory power of the model reduced marginally compared to that of Model 08.

As highlighted earlier, Model 08 reports the highest adjusted $\mathrm{R}$ squared value of approximately $42 \%$. This indicates that, even after incorporating the idiosyncratic volatility, market risk and all other identified risk factors, there is an unexplained component, more specifically of 58\%, of the average stock returns. Perhaps, this might be due to investor behaviour when making the investment decisions; Goetzmann and Kumar (2008) note that the diversification decisions of investors are affected by behavioural biases. Further, Baker and Ricciardi (2014) highlight that the logical thinking of investors is negatively affected by different behavioural biases confronted by them; it prevents the investors from making impartial decisions. Empirical findings of this study are clearly in line with the findings of Cuong and Ishaq (2015) where they note that investor sentiment plays a key role on the association between average stock returns and idiosyncratic volatility.

In addition to the above, as the high $\mathrm{F}$ statistics suggest, the overall significance of each of the models from 02 to 09 is very high (see Table 4). This result ensures the precision of the inferences drawn between average stock returns and idiosyncratic volatility of stocks ${ }^{12}$.

\section{Conclusion}

Although the theory suggests that the idiosyncratic volatility is irrelevant in asset pricing, the empirical evidence clearly shows that the investors demand a premium on idiosyncratic volatility due to their imperfectly diversified investment portfolios. The empirical evidence of this study demonstrates that there is a positive and highly statistically significant association exists between average stock returns and idiosyncratic volatility in the Sri Lankan context. It also indicates that the investors are expecting a higher level of premium for idiosyncratic volatility as they hold imperfectly diversified portfolios.

\footnotetext{
${ }^{12}$ Appendix 2 demonstrates the validity and reliability tests results of the OLS models used in the study.
} 
Further, the empirical findings documented in the current study have number of implications for different stakeholders. The implications for the investment community can be broadly analysed in several viewpoints such as individual investors, arbitrageurs and investment professionals. From the individual investors' point of view, when they attempt to fully diversify their stock portfolios, they need to stretch a special consideration on the small stocks. However, this addition of more stocks into the investment portfolios should be reviewed critically as such addition goes hand in hand with increases the cost of investment.

From a theoretical lens, sale of small sized stocks includes a higher transaction cost so that it makes difficult to gain arbitrage profits from small stocks. Therefore, the arbitrageurs suffer from idiosyncratic volatility particularly with respect to small sized stocks since the small stocks are highly exposed to unsystematic risk. On the other hand, the presence of statistically significant and positive idiosyncratic volatility in the Sri Lankan capital market implies that investment professionals need be vigilant on the composition of the stock portfolios as there is a possibility that the addition of stocks with higher idiosyncratic volatility may dilute the performance of the stock portfolios maintained by them.

Moreover, from the regulators and policy makers point of view, the changes in the macroeconomic environment particularly due to different macroeconomic policies, affect the firms in varying degrees. This leads to a higher level of volatility in the firm specific risk which makes the capital market investments less attractive for potential investors; it negatively affects the investor confidence and hinders the development of the capital market of the country. Hence, regulators and policymakers should focus on implementing stable macroeconomic policies in order to create a conducive investment environment.

\section{Limitations and Further Research}

In addition to the look-ahead biasness problem in in-sample EGARCH idiosyncratic volatility estimates, under certain instances, the sum of the volatility coefficients exceeds unity with respect to certain stocks when estimating the idiosyncratic volatility through EGARCH models. Moreover, Bradrania et al. (2015) show that liquidity is an important determinant of idiosyncratic volatility and it significantly affects the pricing of assets. However, in deriving at the inferences of the current study, the regression specifications in Model 02 to Model 09 have not been controlled for liquidity. Hence, particularly from a frontier market perspective, the impact of the liquidity on the stock returns and idiosyncratic volatility relationship 
remains as an open research question for further research. Further, in the current study, the stock returns have not been adjusted for dividends and share splits where these corporate events might have a direct impact on the idiosyncratic volatility as the stock prices are sensitive to different corporate announcements. Therefore, it is another avenue for further research.

This study further revealed that the idiosyncratic volatility premium becomes stronger when it is controlled for the profitability and investment factors while it is also identified that the investor sentiment plays a key role on the nexus between average stock returns and idiosyncratic volatility. Thus, from the viewpoint of academia, it is a timely factor to be concerned on the investor behaviour as it is much worth to mention that investor behaviour is an interesting area to improve the richness of the existing literature pertinent to average stock returns and idiosyncratic volatility. Therefore, it is important to further study on the sensitivity of the idiosyncratic volatility with respect to profitability and investments of firms while investigating the investor behaviour in light of high idiosyncratic volatility of stocks.

\section{Declaration of Conflicting Interests}

The authors declared no potential conflicts of interest with respect to the research, authorship, and publication of this article.

\section{References}

Aabo, T., Pantzalis, C., \& Park, J. C. (2017). idiosyncratic volatility: An indicatior of noise trading? Joutnal of Banking and Finance, 75, 136-151. http://dx.doi.org/10.1016/j.jbankfin.2016.11.003

Abeysekera, A. P., \& Nimal, P. D. (2016). The impact of the financial sector on asset pricing tests: Evidence from the Colombo Stock Exchange. Asian Journal of Finance \& Accounting, 8(2), 113-124.

https://doi.org/10.5296/ajfa.v8i2.10056

Abeysekera, A. P., \& Nimal, P. D. (2017). The four-factor model and stock returns: Evidence from Sri Lanka. Afro-Asian Journal of Finance and Accounting, 7(1), 1-15. https://doi.org/10.1504/AAJFA.2017.082924

Amihud, Y. (2002). Illiquidity and stock returns: Cross-section and time-series effects. Journal of Financial Markets, 5(1), 31-56.

https://doi.org/10.1016/S1386-4181(01)00024-6

Amihud, Y., \& Mendelson, H. (1986). Asset pricing and the bid-ask spread. Journal of Financial Economics, 17(2), 223-249. https://doi.org/10.1016/0304405X(86)90065-6 
Ang, A., Hodrick, R. J., Xing, Y., \& Zhang, X. (2006). The cross-section of volatility and expected returns. The Journal of Finance, 61(1), 259-299. https://doi.org/10.1111/j.1540-6261.2006.00836.X

Ang, A., Hodrick, R. J., Xing, Y., \& Zhang, X. (2009). High idiosyncratic volatility and low returns: International and further US evidence. Journal of Financial Economics, 91(1), 1-23. https://doi.org/10.1016/j.jfineco.2007.12.005

Angelidis, T. (2010). Idiosyncratic risk in emerging markets. The Financial Review, 45(4), 1053-1078. https://doi.org/10.1111/j.1540-6288.2010.00285.x

Baker, K. H., \& Ricciardi, V. (2014, February). How biases affect investor behaviour. The European Financial Review, 7-10.

https://www.europeanfinancialreview.com/how-biases-affect-investorbehaviour/

Bali, T. G., \& Cakici, N. (2008). Idiosyncratic volatility and the cross section of expected returns? Journal of Financial and Quantitative Analysis, 43(1), 2958. https://doi.org/10.1017/S002210900000274X

Bali, T. G., Cakici, N., \& Whitelaw, R. F. (2011). Maxing out: Stocks as lotteries and the cross-section of expected returns. Journal of Financial Economics, 99(2), 427-446. https://doi.org/10.1016/j.jfineco.2010.08.014

Bali, T. G., Engle, R. F., \& Murray, S. (2016). Empirical asset pricing: The cross section of stock returns. John Wiley \& Sons.

Bradrania, M. R., Peat, M., \& Satchell, S. (2015). Liquidity costs, idiosyncratic volatility and expected stock returns. International Review of Financial Analysis, 42, 394-406. https://doi.org/10.1016/j.irfa.2015.09.005

Brooks, C. (2008). Introductory econometrics for finance ( $2^{\text {nd }}$ ed.). Cambridge University Press.

Carhart, M. M. (1997). On persistence in mutual fund performance. The Journal of Finance, 52(1), 57-82. https://doi.org/10.1111/j.1540-6261.1997.tb03808.x

Cuong, N., \& Ishaq, B. M. (2015). Investor sentiment and idiosyncratic volatility puzzle: Evidence from the Chinese Stock Market. Journal of Stock \& Forex Trading, 4(3). 1-13. https://www.longdom.org/open-access/investor-sentimentand-idiosyncratic-volatility-puzzle-evidence-from-thechinese-stock-market2168-9458-1000158.pdf

Ediriwickrama, T. C. (2018). Using pre-listing information to mitigate initial public offerings' long run underperformance: Evidence from Sri Lanka. Colombo Business Journal, 9(1), 19-44. http://doi.org/10.4038/cbj.v9i1.21

Engle, R. F., \& Ng, V. K. (1993). Time-varying volatility and the dynamic behavior of the term structure. Journal of Money, Credit and Banking 25(3), 336-349. https://doi.org/10.2307/2077766 
Fabozzi, F. J., Gupta, F., \& Markowitz, H. M. (2002). The legacy of modern portfolio theory. The Journal of Investing, 11(3), 7-22. https://doi.org/10.3905/joi.2002.319510

Fama, E. F. (1998). Market efficiency, long-term returns, and behavioral finance. Journal of Financial Economics, 49(3), 283-306. http://dx.doi.org/10.2139/ssrn.15108

Fama, E. F., \& French, K. R., (1992). The cross-section of expected stock returns. The Journal of Finance, 47(2), 427-65. https://doi.org/10.1111/j.15406261.1992.tb04398.x

Fama, E. F., \& French, K. R., (1993). Common risk factors in the returns on stocks and bonds. Journal of Financial Economics, 33(1), 3-56. https://doi.org/10.1016/0304-405X(93)90023-5

Fama, E. F., \& French, K. R. (2004). The capital asset pricing model: Theory and evidence. Journal of Economic Perspectives, 18(3), 25-46. http://dx.doi.org/10.1257/0895330042162430

Fama, E. F., \& French, K. R. (2012). Size, value, momentum in international stock returns. Journal of Financial Economics, 105, 457-472. https://doi.org/10.1016/j.jfineco.2012.05.011

Fama, E. F., \& French, K. R. (2015). A five-factor asset pricing model. Journal of Financial Economics, 116, 1-22. https://doi.org/10.1016/j.jfineco.2014.10.010

Fama, E. F., \& French, K. R. (2017). International tests for a five-factor asset pricing model. Journal of Financial Economics, 123(3), 441-463. https://doi.org/10.1016/j.jfineco.2016.11.004

$\mathrm{Fu}, \mathrm{F}$. (2009). Idiosyncratic risk and the cross-section of expected stock returns. Journal of Financial Economics, 91, 24-37. https://doi.org/10.1016/j.jfineco.2008.02.003

Goetzmann, W. N., \& Kumar, A. (2008). Equity portfolio diversification. Review of Finance, 12(3), 433-463. https://doi.org/10.1093/rof/rfn005

Guo, H., Kassa, H., \& Ferguson, M. F. (2014). On the relation between EGARCH idiosyncratic volatility and expected stock returns. Journal of Financial and Quantitative Analysis, 49(1), 271-296. https://doi.org/10.1017/S0022109014000027

Hou, K., \& Moskowitz, T. J. (2005). Market frictions, price delay, and the crosssection of expected returns. The Review of Financial Studies, 18(3), 981-1020. https://doi.org/10.1093/rfs/hhi023

Jiang, G. J., Xu, D., \& Yao, T. (2009). The infomration content of idiosyncratic volatility. Journal of Financial and Quantitative Analysis, 44(1), 1-28. https://doi.org/10.1017/S0022109009090073 
Kumar, A. (2009). Who gambles in the stock market?. The Journal of Finance, 64(4), 1889-1933. https://doi.org/10.1111/j.1540-6261.2009.01483.x

Kumari, J., Mahakud, J., \& Hiremath, G. S. (2017). Determinants of idiosyncratic volatility: Evidence from the Indian stock market. Research in International Business and Finance, 41, 172-184. https://doi.org/10.1016/j.ribaf.2017.04.022

Liu, S., Kong, A., Gu, R., \& Guo, W. (2019). Does idiosyncratic volatility matter? Evidence form Chinese stock market. Physica A: Statistical Mechanics and Its Applications, 516, 393-401. https://doi.org/10.1016/j.physa.2018.09.184

Malagon, J., Moreno, D., \& Rodriguez, R. (2015). The idiosyncratic volatility anomaly: Corporate investment or investor mispricing? Journal Banking \& Finance, 60, 224-238. http://dx.doi.org/10.1016/j.jbankfin.2015.08.014

Malkiel, B., \& Xu, Y. (2006). Idiosyncratic risk and security returns [Unpublished manuscript]. The University of Texas at Dallas. https://personal.utdallas.edu/ yexiaoxu/IVOT_H.PDF

Markowitz, H. (1952). Portfolio selection. The Journal of Finance, 7(1), 77-91. https://doi.org/10.1111/j.1540-6261.1952.tb01525.x

Merton, R. C. (1987). A simple model of capital market equilibrium with incomplete information. The Journal of Finance, 42(3), 483-510. https://doi.org/10.1111/j.1540-6261.1987.tb04565.x

Miller, M. H., \& Scholes, M. S. (1982). Dividends and taxes: Some empirical evidence. The Journal of Political Economy, 90(6), 1118-1141. https://doi.org/10.1086/261114

Nartea, G. V., Ward, B. D., \& Yao, L. J. (2010). Idiosyncratic volatility and crosssectional stock returns in Southeast Asian stock markets. Accounting \& Finance, 51(4), 1031-1054. https://doi.org/10.1111/j.1467-629X.2010.00384.x

Nartea, G. V., Wu, J., \& Liu, Z. (2013). Does idiosyncratic volatility matter in emerging markets? Evidence from China. Journal of International Financial Markets, Institutions and Money, 27, 137-160. https://doi.org/10.1016/j.intfin.2013.09.002

Nelson, D. B. (1991). Conditional heteroskedasticity in asset returns: A new approach. Econometrica, 59(2), 347-370. https://www.jstor.org/stable/2938260

Pastor, L., \& Stambaugh, R. F. (2003). Liquidity risk and expected stock returns. The Journal of Political Economy, 111(3), 642-685. https://doi.org/10.1086/374184

Pukthuanthong-Le, K., \& Visaltanachoti, N. (2009). Idiosyncratic volatility and stock returns: A cross country analysis. Applied Financial Economics, 19(16), 1269-1281. https://doi.org/10.1080/09603100802534297 
Ross, S. A. (1976). The arbitrage theory of capital asset pricing. Journal of Economic Theory, 13(3), 341-360. https://doi.org/10.1016/00220531(76)90046-6

Samarakoon, L. P. (1996). Predictability of short-horizon returns in the Sri Lankan stock market. Sri Lankan Journal of Management, 1(3), 207-224, https://ssrn.com/abstract=1395059

Sharpe, W. F. (1964). Capital asset prices: A theory of market equilibrium under conditions of risk. The Journal of Finance, 19(3), 425-442. https://www.jstor.org/stable/2977928

Sriyalatha, M. A. K. (2008). Does the All Share Price Index represent the Colombo stock market? The Meijo Review, 9(3), 75-90. http://wwwbiz.meijou.ac.jp/SEBM/ronso/no9_3/07_SRIYALATHA.pdf

Uludag, B. K., \& Ezzat, H. (2016). Are frontier markets worth the risk? In P. Andrikopoulos, G. Gregoriou, \& V. Kallinterakis (Eds.), Handbook of frontier markets: Evidence from Asia and international comparative studies (pp. 67-80). Academic Press.

Xu, Y., \& Malkiel, B. (2003). Investigating the behaviour of idiosyncratic volatility. The Journal of Business, 76(4), 613-645. https://www.jstor.org/stable/10.1086/377033

Zhong, A. (2018). Idiosyncratic volatility in the Australian equity market. PacificBasin Finance Journal, 50, 105-125. https://doi.org/10.1016/j.pacfin.2017.06.010

\section{Appendix 1: Adjustment of Stock Returns to Corporate Events}

$Q_{i t}=\left(\frac{P_{i, t-1}}{P_{i, t-1}+\beta_{i, t} X A_{i, t}}\right)\left(1+\alpha_{i, t}+\beta_{i, t}+\gamma_{i, t}\right) \lambda_{i, t}+\frac{D_{i, t}}{P_{i, t}}$

where, $i$ denotes individual stock $i$ at time (month) $t$ while $p$ is the monthly closing stock price of stock $i$. $Q$ is the adjustment multiplier where $A$ is the offer price per share on rights issue and $D$, the cash dividend. $\alpha$ is the ratio of bonus issues and $\beta$ is the ratio of rights issues while $\gamma$ and $\lambda$ are ratio of stocks on stock dividends and ratio of changing face values respectively.

As in Sriyalatha (2008), a sample adjustment of stock returns to the corporate events (bonus issues and rights issues) occurred in the year 2011 can be shown as follows. 


\begin{tabular}{|c|c|c|c|c|c|}
\hline 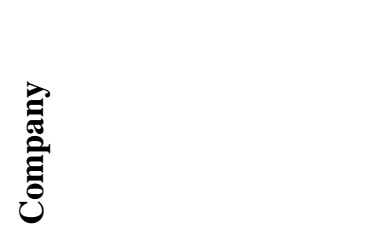 & 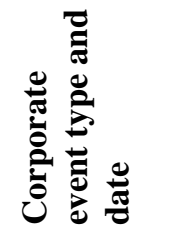 & 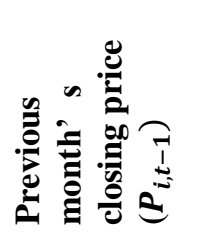 & 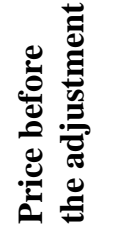 & 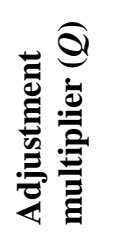 & 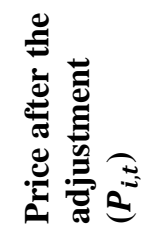 \\
\hline $\begin{array}{l}\text { Royal Ceramics Lanka } \\
\text { PLC }\end{array}$ & $10-\operatorname{Jan}(\mathrm{B})$ & 304.90 & 160.20 & 2.0000 & 320.40 \\
\hline $\begin{array}{l}\text { Browns Beach Hotels } \\
\text { PLC }\end{array}$ & $11-\operatorname{Jan}(\mathrm{R})$ & 78.00 & 72.10 & 1.1489 & 82.84 \\
\hline Dunamis Capital PLC & 24-Jan (R) & 15.20 & 15.10 & 1.0734 & 16.21 \\
\hline Lanka Walltile PLC & 8-Feb (B) & 164.00 & 176.30 & 1.2000 & 211.56 \\
\hline Marawila Resorts PLC & 21-Feb (R) & 13.20 & 12.40 & 1.0510 & 13.03 \\
\hline $\begin{array}{l}\text { East West Properties } \\
\text { PLC }\end{array}$ & 14-Mar (R) & 13.30 & 10.70 & 1.2286 & 13.15 \\
\hline CT Holdings PLC & 28-Apr (R) & 200.00 & 209.40 & 0,9991 & 209.21 \\
\hline $\begin{array}{l}\text { Lankem Developments } \\
\text { PLC }\end{array}$ & 21-Apr (R) & 72.30 & 30.90 & 2.5862 & 79.91 \\
\hline $\begin{array}{l}\text { Seylan Developments } \\
\text { PLC }\end{array}$ & 12-May (R) & 15.10 & 13.30 & 1.1571 & 15.39 \\
\hline Serendib Hotels PLC & 5-May (R) & 171.80 & 30.80 & 1.2070 & 37.17 \\
\hline Ceylon Cold Stores PLC & 30-Jun (R) & 726.10 & 600.00 & 1.0564 & 633.81 \\
\hline $\begin{array}{l}\text { Singalanka Standard } \\
\text { Chemicals PLC }\end{array}$ & 11-Aug (R) & $2,189.00$ & 305.70 & 3.7196 & $1,137.09$ \\
\hline On'ally Holdings PLC & 6-Sep (B) & 90.40 & 74.90 & 1.2500 & 93.63 \\
\hline
\end{tabular}

Note: (B) and (R) denote the bonus issues and rights issues respectively.

Appendix 2: Validity and Reliability of OLS Results

Multicollinearity Test - Variance Inflation Factor (VIF)

\begin{tabular}{lcccccccc}
\hline & \multicolumn{7}{c}{ Model } \\
\cline { 2 - 8 } & $\mathbf{0 2}$ & $\mathbf{0 3}$ & $\mathbf{0 4}$ & $\mathbf{0 5}$ & $\mathbf{0 6}$ & $\mathbf{0 7}$ & $\mathbf{0 8}$ & $\mathbf{0 9}$ \\
\hline EIVOL & 1.0153 & 1.0126 & 1.0240 & 1.0174 & 1.0187 & 1.0272 & 1.0516 & 1.0437 \\
$R_{m}-R_{f}$ & & 1.0185 & & & & & 1.1566 & 1.0549 \\
$S M B$ & & & 1.0221 & & & & 1.1460 & 1.1287 \\
$H M L$ & & & & 1.0021 & & & 1.1875 & \\
$R M W$ & & & & & 1.0072 & & 1.2120 & 1.1203 \\
$C M A$ & & & & & & 1.0358 & 1.1147 & 1.0624 \\
\hline
\end{tabular}


Heteroscedasticity Test - Breusch Pagan Godfrey test

\begin{tabular}{lcccccccc}
\hline & 03 & \multicolumn{1}{c}{ Model } \\
\cline { 2 - 9 } & 02 & 03 & 04 & 05 & 06 & 07 & 08 & 09 \\
\hline $\begin{array}{l}\text { Prob. Chi- } \\
\text { Square }\end{array}$ & 0.7553 & 0.547 & 0.4672 & 0.8798 & 0.6557 & 0.8594 & 0.9472 & 0.9092 \\
\hline
\end{tabular}

Serial Correlation Test - Breusch Godfrey Serial Correlation LM Test

\begin{tabular}{lcccccccc}
\hline & \multicolumn{7}{c}{ Model } \\
\cline { 2 - 8 } & 02 & 03 & 04 & 05 & 06 & 07 & 08 & 09 \\
\hline $\begin{array}{l}\text { Prob. Chi- } \\
\text { Square }\end{array}$ & 0.202 & 0.2654 & 0.1589 & 0.1047 & 0.1127 & 0.2647 & 0.4291 & 0.1318 \\
\hline
\end{tabular}

Normality Test - Jarque Bera (JB) Test

\begin{tabular}{lcccccccc}
\hline & \multicolumn{8}{c}{ Model } \\
\cline { 2 - 9 } & 02 & 03 & 04 & 05 & 06 & 07 & 08 & 09 \\
\hline Jarque-Bera & 1.1586 & 2.2068 & 4.5030 & 3.0107 & 3.3685 & 1.2755 & 4.2766 & 4.4731 \\
Probability & 0.5603 & 0.3317 & 0.1052 & 0.2219 & 0.1856 & 0.5285 & $0 . .1179$ & 0.1068 \\
\hline
\end{tabular}

